\title{
Letter to the editor: Labral calcification plays a key role in hip pain and symptoms in femoroacetabular impingement
}

\author{
Mingjin Zhong ${ }^{1,2^{*}}$ D, Kan Ouyang ${ }^{1,2}$ and Wei Lu ${ }^{1,2}$
}

\section{To the Editor:}

Recently, we have read the research article entitled "Labral calcification plays a key role in hip pain and symptoms in femoroacetabular impingement" by Trisolino $\mathrm{G}$ and his colleagues [1]. The authors investigated the joint tissue status at the time of arthroscopic treatment for FAI and found a new insight into the relationship between femoroacetabular impingement (FAI) and hip osteoarthritis (OA). We really appreciate the work that has been done by the authors. However, we would also like to point some of our concerns regarding the paper.

First, the authors did not collect normal labrum samples from healthy hip joints. We have known that calcification deposition could also be found in healthy labral tissues [2]. Thus, labral calcification may not just be considered as a result or byproduct of impingement and degeneration, but rather seems a normal physiological process.

Second, FAI involved the abutment of the femoral head against the acetabulum in a hip flexed-adductedinternally rotated position, impinging the anterior-superior portion of the labrum, and resulting in varied and limited labrum lesion [3]. Accordingly, we speculate that the intraoperative collected labrum specimens reflect the limited anterosuperior region, but in absolute terms, only a small part of the acetabular labrum. However, OA is a whole-joint disorder involving the whole part of the acetabular labrum. Therefore, only the anterior-superior

\footnotetext{
* Correspondence: sportsmedzhong@sina.com

${ }^{1}$ Department of Sports Medicine, The First Affiliated Hospital of Shenzhen University, Health Science Center, Shenzhen, China

${ }^{2}$ The Second People's Hospital of Shenzhen, No.3002 Sungang West Road, Futian district, Shenzhen 518000, Guangdong province, China
}

part of each labrum from end-stage OA patients should be collected in order to avoid selection bias.

Third, several studies have characterized the calcification of soft tissues in the end-stage OA hip joints $[2,4]$. To our knowledge, the calcified hyaline articular cartilage contained basic calcium phosphate (BCP) and calcium pyrophosphate dihydrate (CPPD) crystals; however, only CPPD and no BCP crystals deposited in the acetabular labrum [2]. It is not clear whether BCP crystals could be found in labrum calcification of FAI patients. We do think the pathophysiologic characteristics of the labrum calcification studied do not appear to be from degenerative changes, but a separate pathophysiologic process from damage to the labrum from FAI leading to a calcific response [5]. This needs to be confirmed in future studies.

Moreover, the authors concluded that a higher local concentration of calcium crystal deposition in the labrum could lead to a higher pain level and worse functional sore. Previous study stated that the amount of calcification in the labrum instead of histological degeneration grade had a significant influence on the preoperative Harris Hip Score (HHS) in patients with endstage OA [2, 4]. Therefore, how much amount of calcium crystal deposition in the labrum produce adverse effect on hip function in patients with FAI need further study.

\section{Abbreviations \\ BCP: Basic calcium phosphate; CPPD: Calcium pyrophosphate dihydrate; FAl: Femoroacetabular impingement; HHS: Harris Hip Score; OA: Osteoarthritis}

\section{Acknowledgements}

None. 


\section{Authors' contributions}

MJZ: concept and writing. K OY: writing. WL: concept and revising. The authors have read and approved the final manuscript.

\section{Funding}

This study was funded by the Shenzhen Second People's Hospital clinical research project (grant number 20193357019)

Availability of data and materials

Not applicable.

\section{Ethics approval and consent to participate}

Not applicable.

\section{Consent for publication}

Not applicable.

\section{Competing interests}

The authors declare that they have no competing interests.

Received: 24 April 2020 Accepted: 5 June 2020

Published online: 12 June 2020

\section{References}

1. Trisolino G, Favero M, Dallari D, Tassinari E, Traina F, Otero M, et al. Labral calcification plays a key role in hip pain and symptoms in femoroacetabular impingement. J Orthop Surg Res. 2020;15(1):86.

2. Hawellek T, Hubert J, Hischke S, Krause M, Bertrand J, Schmidt BC, et al. Calcification of the acetabular labrum of the hip: prevalence in the general population and relation to hip articular cartilage and fibrocartilage degeneration. Arthritis Res Ther. 2018;20(1):104.

3. Philippon MJ, Bolia I, Locks R, Utsunomiya H. Treatment of femoroacetabular impingement: labrum, cartilage, osseous deformity, and capsule. Am J Orthop (Belle Mead NJ). 2017;46(1):23-7.

4. Hubert J, Hawellek T, Moe M, Hischke S, Krause M, Rolvien T, et al. Labral calcification in end-stage osteoarthritis of the hip correlates with pain and clinical function. J Orthop Res. 2018:36(4):1248-55.

5. Perets I, Hartigan DE, Walsh JP, Chen AW, Mu BH, Domb BG. Excision of labral amorphous calcification as a part of hip arthroscopy-clinical outcomes in a matched-controlled study. Arthroscopy. 2018;34(4):1227-33.

\section{Publisher's Note}

Springer Nature remains neutral with regard to jurisdictional claims in published maps and institutional affiliations.

Ready to submit your research? Choose BMC and benefit from:
- fast, convenient online submission
- thorough peer review by experienced researchers in your field
- rapid publication on acceptance
- support for research data, including large and complex data types
- gold Open Access which fosters wider collaboration and increased citations
- maximum visibility for your research: over 100M website views per year
At BMC, research is always in progress.
Learn more biomedcentral.com/submissions

